\title{
KONSEP PENDIDIKAN ISLAM BAGI REMAJA MENURUT ZAKIAH DARADJAT
}

\author{
Zulkifli Agus \\ Sekolah Tinggi Ilmu Tarbiyah Raudhatul Ulum Sakatiga \\ Email: zulkifli@stit-ru.ac.id
}

\begin{abstract}
Abstrak
Masa remaja merupakan masa persiapan untuk menjadi dewasa yang matang dan sehat. Pendidikan Islam sangat penting dalam membimbing dan mengarahkan remaja. Karena pada masa remaja ini seseorang akan mengalami kegoncangan dan ketidaksatabilan emosi, kebimbangan dalam mencari pegangan hidup, dan keyakinan remaja pada Tuhan dan agama akan semakin goncang juga apabila terdapat perbedaan antara nilai yang dipelajarinya dengan kelakuan orang dalam masyarakat. Maka dari itu tanggung jawab pendidikan terletak pada orang tua, guru dan masyarakat untuk mencapai tujuan pendidikan Islam.

Tujuan penelitian ini merupakan salah satu upaya mencari jawaban masalah di atas, diharapkan dengan pendidikan Islam menurut Zakiah Daradjat, adalah untuk membimbing remaja agar remaja tetap sehat mental, berakhlak mulia dan takwa kepada Allah SWT.

Dari hasil penelitian ini, maka dapat penulis simpulkan pendidikan dalam Islam begitu penting sehingga merupakan suatu kewajiban, karena pendidikan dapat mengubah manusia dari tidak tahu menjadi tahu. Terkhusus pendidikan pada remaja. Pendidikan remaja dengan pendidikan yang Islami, dalam arti Islami mengadung makna bahwa setiap jenis pendidikan yang diberikan pada remaja harus dengan nilai agama (Islam), karena nilai agama merupakan ajaran yang absolut, berlaku sepanjang zaman sehingga nilai-nilai yang lainnya mengikuti nilai-nilai Islam.Tanggung jawab pendidikan pada remaja terletak dan dipengaruhi oleh orang tua, guru, dan masyarakat. Dengan demikian bahwa tanggung jawab pendidikan dalam Islam bersifat perseorangan dan sosial sekaligus. Dan peranan agama sebagai fungsi pendidikan Islam bagi remaja sangat penting. Karena remaja yang memiliki dasar-dasar agama akan lebih mudah dikembalikan pada jiwanya yang beragama apabila ia melenceng perbuatannya, jika dibandingkan dengan remaja yang tidak dibekali pendidikan agama akan goncang sampai ia dewasa.
\end{abstract}

Kata Kunci: Pendidikan Islam, Remaja, Zakiah Daradjat

\section{Konsep Pendidikan Islam}

Sesuatu yang diharapkan terwujud setelah orang mengalami pendidikan Islam secara keseluruhan, yaitu kepribadian seseorang yang membuatnya menjadi "insan kamil" dengan pola takwa Insan Kamil artinya manusia utuh rohani dan jasmani, dapat hidup dan berkembang secara wajar dan normal karena takwanya kepada Allah SWT. Ini mengandung arti bahwa pendidikan Islam itu diharapkan menghasilkan manusia yang berguna bagi dirinya dan masyarakatnya serta senang dan gemar mengamalkan dan mengembangkan ajaran Islam dalam berhubungan dengan Allah dan dengan manusia sesamanya, dapat mengambil manfaat yang 


\section{Konsep Pendidikan Islam Bagi Remaja Menurut Zakiah Daradjat Zulkifli Agus}

semakin meningkat dari alam semesta ini untuk kepentingan hidup di dunia kini dan di akhirat nanti.

Cara atau alat yang paling efektif dan efisisen untuk mencapai tujuan pendidikan ialah pengajaran. Karena itu pengajaran sering diidentikkan dengan pendidikan, meskipun kalau istilah ini sebenarnya tidak sama. Pengajaran ialah poros membuat menjadi terpelajar (tahu, mengerti, mengusai, ahli: belum tentu menghayati dan meyakini), sedang pendidikan ialah membuat orang jadi terdidik (mempribadi, menjadi adat kebiasaan).(Zakiah Daradjat,2014: 29-30)

Tujuan pengajaran ialah mengembangkan dan penjabaran dari tujuan pendidikan, yaitu tujuan pendidikan Islam. Tujuan pendidikan Islam ialah kepribadian muslim yang dalam istilah al-Qur'an disebut "Muttaqin", yaitu orang yang bertakwa kepada Allah, Tuhan Pencipta dan Pemelihara manusia dan alam semesta.(Zakiah Daradjat,2008: 74.)

Maka dari itu pengajaran merupakan alat yang cukup urgen dalam melaksanakan pendidikan Islam guna mempribadikan remaja.

\section{Kebutuhan-Kebutuhan Remaja}

Dalam melakukan pengajaran dalam pendidikan yang akan diberikan pada remaja terlebih dahulu harus diketahui kebutuhan-kebutuhan remaja.

Kebutuhan primer atau kebutuhan fisik remaja pada umumnya tidak banyak bedanya dari kebutuhan anak-anak. Mereka juga membutuhkan semua yang dibutuhkan oleh makhluk hidup pada umumnya, seperti makan, minum, istirahat, kegiatan, tidur, oksigen dan sebagainya. Adapun kebutuhan sekunder dan kebutuhan kejiwaan remaja agak berbeda dari kebutuhan kejiwaan kanak-kanak, baik dipandang dari jenis maupun kualitas kebutuhan. Remaja memerlukan kebutuhan-kebutuhan tertentu yang sesuai dengan perkembangan emosinya, di antaranya:

a) Kebutuhan Akan Pengendalian Diri

Remaja membutuhkan pengendalian diri, karena dia belum mempunyai pengalaman yang memadai untuk itu. Dia sangat peka, karena pertumbuhan fisik dan seksual yang berlangsung dengan cepat. Sebagai akibat dari pertumbuhan fisik dan seksual yang cepat itu, terjadi kegoncangan dan kebingungan dalam dirinya.(Zakiah Daradjat,1995: 17).

Mungkin juga dia hilang kendali terhadap kelakuan dan tindakannya, atau mungkin juga ia condong kepada menyendiri dan menutup diri. Di samping itu remaja merasa bahwa fisiknya sudah seperti orang dewasa, sehingga dia merasa harus bertingkah laku seperti orang dewasa, agar dapat merasa aman. Oleh karena itu ia perlu memperkuat kendali, terhadap kelakuan yang dituntut oleh masyarakat. 
Volume 4 Nomor 1 Edisi Juni 2019

P-ISSN : 2541-3686

b) Kebutuhan Akan Kebebasan

Kebebasan emosional dan materi merupakan kebutuhan remaja pula pada masa-masa ini. Tidak diragukan lagi, kematangan fisik mendorong remaja untuk berusaha mandiri dan bebas dalam mengambil keputusan untuk dirinya, sehingga dia dapat mencapai kematangan emosional yang terlepas dari emosi orang tua dan keluarganya. Kadang-kadang orang tua menghalangi hal tersebut, dengan alasan kasihan kepadanya. Banyak orang tua sangat memperhatikan dan membatasi sikap, perilaku, dan tindakan-tindakan remaja. Dengan demikian remaja merasa tidak dipercayai oleh orang tua dan mereka tidak dapat menerima hal tersebut, sehingga remaja berontak. Akan tetapi sebaliknya, remaja masih memerlukan orang tua, terutama dari segi materi dan emosi. Oleh karena itu, kebutuhan remaja sering bertentangan satu sama lain. Jika hal itu tidak teratasi, mungkin saja remaja itu akan mengalami konflik kejiwaan.

c) Kebutuhan Akan Rasa Kekeluargaan

Kebutuhan remaja yang bertentangan satu sama lain, menyebabkannya merasa tidak aman, di mana keinginannya untuk mandiri dan bebas berlawanan dengan kebutuhan untuk bergantung kepada orang tua. Hilangnya rasa aman, menimbulkan suatu dorongan baru, yaitu kebutuhan akan rasa kekeluargaan, artinnya dia adalah bagian dari keluarganya, dan bangga dengan keluarga tersebut. Kebutuhan ini berkembang dan tidak terbatas pada keluarga saja, tetapi juga pada kelompok teman sepermainan, kelompok organisasi, tim olah raga, klub kesenian, kebudayaan dan sebagainya, di mana mereka terikat oleh bakat, keinginan serta tujuaan dan nilai-nilai tertentu.

d) Kebutuhan Akan Penerimaan Sosial

Remaja membutuhkan rasa diterima oleh orang-orang dalam lingkungannya, di rumah, di sekolah atau dalam masyarakat di mana dia tinggal. Merasa diterima oleh orang tua dan keluarga, merupakan faktor penting untuk mencapai rasa di terima oleh masyarakat.

e) Kebutuhan Akan Penyesuaian Diri

Penyesuaian diri dibutuhkan oleh setiap orang dalam tahap pertumbuhan mana pun, dan lebih dibutuhkan pada usia remaja, karena pada usia ini remaja banyak mengalami kegoncangan dan perubahan dalam dirinya. Apabila seseorang tidak berhasil menyesuaikan diri pada masa kanak-kanaknya, dia dapat mengejarnya pada usia remaja. Akan tetapi apabila tidak dapat menyesuaikan diri pada usia remaja, maka kesempatan untuk perbaikan itu mungkin akan hilang untuk selama-lamanya, kecuali dengan pengaruh pendidikan dan usaha khusus.(Zakiah Daradjat,1995:18-19)

f) Kebutuhan Akan Agama dan Nilai-nilai

Kebutuhan remaja kadang-kadang tidak dapat dipenuhi bila berhadapan dengan agama, nilai-nilai sosial dan adat kebiasaan, terutama apabila pertumbuhan 


\section{Konsep Pendidikan Islam Bagi Remaja Menurut Zakiah Daradjat Zulkifli Agus}

sosialnya sudah matang, yang seringkali mengusai pikiran dan kehidupannya. Pertentangan tersebut semakin menajam bila remaja berhadapan dengan berbagai situasi, misalnya film yang menayangkan penampilan yang tidak sopan, mode pakaian yang seronok, buku-buku bacaan, majalah, koran yang sering menyajikan gambar tanpa mengindahkan kaidah moral dan agama, dan sebagainya. Semuanya itu menyebabkan remaja semakin membutuhkan pemahaman akan ajaran agama, nilai-nilai akhlak, serta nilai-nilai sosial, untuk membantunya dalam melawan pengaruh dan dorongan buruk, sebagai akibat dari situasi seperti tersebut.(Zakiah Daradjat,1995:20).

Dengan kebutuhan remaja yang begitu cukup banyak, sudah seharusnyalah orang tua memperhatikan, membimbing, membina dan mendidik putra-putrinya agar mereka tumbuh dan berkembang sebagaimana mestinya sesuai fitrah dan kodratnya.

\section{Jenis-Jenis Pendidikan Islami bagi Remaja}

Adapun jenis-jenis pendidikan Islami bagi remaja menurut Zakiah Daradjat adalah sebagai berikut.

a) Pendidikan Agama/Keimanan

Zakiah Daradjat mengemukakan dalam “Ilmu Jiwa Agama” demikian pula halnya dengan pendidikan agama, remaja telah sampai kepada mampu memahami hal yang abstrak dan mampu mengambil kesimpulan yang abstrak dari kenyataan yang dilihat atau didengarnya, maka pendidikan agama tidak akan diterimanya begitu saja tanpa memahaminya. Apa yang dulu waktu masa kanak-kanak dapat diterimanya tanpa bertanya, tapi pada umur ini, ia akan sering bertanya atau minta penjelasan yang masuk akal, karena mereka tidak dapat menerima apa yang tidak dapat dimengertinya. (Zakiah Daradjat,1915:135).

Ajaran agama yang begitu baik tidak cukup hanya sekedar diketahui dan dimengerti. Agama akan berpengaruh dan ikut menentukan kesehatan mental, ialah apabila agama itu dilaksanakan dalam hidup. Pelaksaan agama dalam hidup itu, bukanlah hanya sekedar melaksanankan saja, akan tetapi harus seluruh kehidupan dikendalikan dan dibimbing oleh agama. Mungkinnya agama menjadi penentu kebahagiaan dan ketenangan hidup, adalah apabila agama itu masuk terjalin dalam kepribadian. Untuk itu diperlukan pendidikan agama, yang terlaksana bersamasama dengan pembinaan pribadi.(Zakiah Daradjat,1985:15)

Oleh karena itu orang tua, guru, dan masyarakat hendaknya dapat memahami betul-betul perkembangan jiwa agama yang sedang dilalui oleh remaja agar pendidikan agama dapat dilaksanakan dengan berhasil dan berdaya guna.

b) Pendidikan Akhlak/Moral

Menurut Zakiah Daradjat, bahwa "Akhlak anak di dalam implementasi iman dalam segala bentuk perilaku". Adapun akhlak yang diberikan menurutnya adalah: 
Volume 4 Nomor 1 Edisi Juni 2019

P-ISSN : 2541-3686

1) Akhlak terhadap orang tua.

2) Akhlak terhadap orang lain.

3) Akhlak dan penampilan diri.(Zakiah Daradjat,1993:58).

Untuk membina akhlak agar mempunyai sifat-sifat terpuji, tidaklah mungkin dengan penjelasan pengertian saja, akan tetapi perlu membiasakannya untuk melakukan yang baik yang diharapkan nanti dia akan mempunyai sifat-sifat itu, dan menjauhi sifat tercela. Kebiasaan dan latihan itulah yang membuat dia cenderung kepada melakukan yang baik dan meninggalkan yang kurang baik.(Zakiah Daradjat,1993: 58).

Akhlak berkenaan dengan implementasi iman dalam bentuk tingkah laku, pemberian pendidikan akhlak pada remaja harus sesuai antara penjelasan yang diberikan (nilai-nilai akhlak yang diajarkan) dengan bentuk perbuatan yang ada pada orang tua, guru, bahkan tokoh-tokoh agama dan masyarakat.

c) Pendidikan Intelektual/Akal

Dalam diri manusia terdapat sesuatu yang tidak ternilai harganya, sebagai anugrah Tuhan yang tidak diberikan kepada makhluk lainnya, yaitu "akal". Dengan adanya akal, segala anggota manusia, gerak, dan diamnya, semuanya berarti dan berharga. Akal itu dapat digunakan untuk berpikir dan memperhatikan segala benda dan barang yang ada di alam ini.(Zakiah Daradjat,1993:46).

Timbulnya ilmu pengetahuan, disebabkan kebutuhan-kebutuhan manusia yang berkemauan hidup berbahagia. Dalam mencapai dan memenuhi kebutuhan hidupnya itu, manusia menggunakan akal pikirannya.(Zakiah Daradjat: 1993:47).

Zakiah Daradjat mengatakan akal pusatnya di otak, digunakan untuk berpikir. "Akal itu merupakan alat untuk menuntut ilmu dan ilmu merupakan alat untuk menyesuaikan kesulitan manusia".(Zakiah Daradjat,1993: 4).

Dalam proses perkembangannya, akal mengikuti pertumbuhan fisik anak, kemampuan berpikir anak yang berusia balita berbeda dengan kemampuan berpikir anak remaja, pemberian pengetahuan kepada anak disesuaikan dengan umur dan kemampuan daya serap anak.

Akal yang berpusat di otak, mengikuti pertumbuhan fisik remaja, maka pemberian pengetahuan kepada remaja disesuaikan dengan tingkat berpikirnya yang sudah memahami hal yang abstrak dari kenyataan yang dilihatnya. Jika pengetahuan itu tidak sesuai dengan logika atau kenyataan, maka remaja akan semakin goncang dan semakin bingung.

d) Pendidikan Psikis

Oleh ahli jiwa dikatakan bahwa pengaruh mental dapat dilihat pada perasaan, pikiran, kelakuan dan kesehatan jasmani. Maka ketenangan jiwa adalah modal pertama yang harus dimiliki oleh setiap orang yang merindukan kebahagiaan hidup. Dalam al-Qur'an banyak terkandung ajaran-ajaran mental yang benar-benar 


\section{Konsep Pendidikan Islam Bagi Remaja Menurut Zakiah Daradjat Zulkifli Agus}

dapat membawa kepada ketenangan dan kebahagiaan itu. Misalnya dalam Surat ArRa'd, ayat 28:

Artinya:

(yaitu) orang-orang yang beriman dan hati mereka menjadi tentram dengan mengingat Allah, hanya dengan mengingat Allah hati menjadi tentram.(Depag. RI. Al-Qurán dan Terjemahnya:252).

Bagi jiwa yang sedang gelisah, agama akan memberi jalan dan siraman penenang hati. Tidak sedikit mendengar orang yang kebingungan dalam hidupnya selama ia belum beragama, tetapi setelah mulai mengenal dan menjalankan agama, ketenangan jiwa akan datang.(Zakiah Darajat,1985: 61).

Dalam memberikan pendidikan psikis pada remaja, pendidik atau orang tua harus menanamkan nilai-nilai keimanan pada remaja, terutama keimanan kepada Allah, karena iman berpengaruh terhadap kejiwaan remaja, kebutuhan jiwa akan terasa tentram, damai dan bahagia. Pendidikan psikis pada remaja harus dibarengi dengan pendidikan agama, karena pendidikan agama berkaitan erat dan memiliki peranan penting dengan pendidikan psikis.

e) Pendidikan Sosial

Manusia adalah makhluk sosial. Tidak ada seorang pun yang sanggup hidup tanpa tergantung kepada masyarakat di sekitarnya. Manusia hidup mulai dari dalam kandungan, kemudian melalui tahapan-tahapan: kanak-kanak, remaja, dewasa dan tua selalu membutuhkan atau bergantung kepada lingkungan sosialnya.(Zakiah Daradjat: 1995:20).

Pendidikan sosial ini sangat dibutuhkan remaja dengan bimbingan dan tauladan, agar mereka dapat melalui masa-masa goncang dengan sukses, lebih mandiri dan remaja dapat merasa bahwa dirinya dihargai dalam lingkungan sosial.

\section{Tanggung Jawab Pendidikan bagi Remaja}

Sehubungan dengan beberapa jenis pendidikan di atas yang bertanggung jawab atas pendidikan remaja adalah orang tua, guru dan masyarakat.

a) Orang Tua

Orang tua merupakan pendidik utama dan pertama bagi anak-anak mereka, karena dari merekalah anak mula-mula menerima pendidikan. Dengan demikian bentuk pertama dari pendidikan terdapat dalam kehidupan keluarga.

Pada umumnya pendidikan dalam rumah tangga itu bukan berpangkal tolak dari kesadaran dan pengertian yang lahir dari pengetahuan mendidik, melainkan karena secara kodrati suasana dan sturukturnya memberikan kemungkinan alami membangun situasi pendidikan. Situasi pendidikan mempengaruhi secara timbal balik antara orang tua dan anak. Orang tua atau ibu dan ayah memegang peran yang penting dan amat berpengaruh atas pendidikan anak-anaknya.(Zakiah Daradjat,2014: 35) 
Volume 4 Nomor 1 Edisi Juni 2019

P-ISSN : 2541-3686

1) Cara Bapak/Ayah Memperlakukan Remaja

Bapak yang bersikap tegas dalam pendidikan anak-anaknya. Dia adalah bapak yang mendidik anaknya dengan cara yang masuk akal atau logis. Dia dapat memahami segala persoalan dan kebutuhan anaknya, kalau perlu ia tegas melarang apa yang dipandangnya tidak baik. Biasanya dia menjelaskan kepada anaknya apa akibat perbuatan yang dilarangnya itu sampai si anak dapat memahami apa alasan larangannya tersebut.

Pada umumnya bapak yang seperti itu banyak menggunakan persuasi dan dorongan, bukan perintah. Jika dia menghukum anaknya atas suatu kesalahan, hukumannya seimbang dengan kesalahan yang dibuatnya.

Remaja yang mempunyai bapak seperti ini biasanya amat menjaga aturanaturan atau ketentuan bapaknya. Dia memahami nasihat bapaknya. Jika dilanggarnya dia sendiri yang akan rugi.

Biasanya remaja yang hidup pada keluarga seperti ini, sayang dan hormat kepada bapaknya, dia berani mengungkapkan perasaan dan pendapatnya.(Zakiah Daradjat,1995: 22-23).

\section{2) Cara Ibu Memperlakukan Remaja}

Pendidik pertama atau pembina utama bagi kepribadian anak adalah ibu, karena pada tahun-tahun pertama dari pertumbuhannya, anak lebih banyak berhubungan dengan ibunya dari pada bapaknya.(Zakiah Daradjat,1990: 11).

Ada ibu yang kurang memperhatikan anaknya yang sudah remaja. Anaknya dibiarkannya tanpa bimbingan, pendidikan dan pengawasan atau pengawasan itu dilimpahkan kepada pembantu. Boleh jadi ia tidak mempunyai waktu untuk memperhatikan anaknya karena dia sibuk bekerja di luar rumah. Mungkin juga ia ada di rumah, akan tetapi dia tidak memberikan perhatian kepada anaknya karena dia sibuk dengan dirinya sendiri atau mempunyai masalah dalam keluarga. Si anak akan merasa tidak terikat kepada orang tuanya dan mudah terpengaruh oleh orangorang di luar keluarganya.

Ibu yang baik memberikan perhatian yang cukup kepada anaknya. Ia dapat memperhatikan, membimbing dan mendorong anaknya kepada hal yang baik tanpa ikut campur tangan dalam urusan pribadi anaknya. Apabila ibu sibuk bekerja di luar rumah, perhatian kepada anaknya tetap ada. Bila ada waktu dia memberi kesempatan kepadanya untuk berdialog, mengeluh, atau minta pertimbangan. Biasanya anak-anak yang mendapat perhatian dari orang tuanya, merasa disayangi dan dia juga menyayangi ibunya dan menjaga dirinya dalam pergaulan.(Zakiah Daradjat,1995: 23).

Ibu yang mengerti dan memperhatikan anaknya dalam semua sikap dan keadaannya akan dapat dengan bijaksana membantu si anak untuk memilih pengaruh yang baik dan menghindari yang tidak baik. Selama si anak melalui umur pertumbuhan sampai mencapai usia remaja. Gejolak dan gelombang jiwa yang 


\section{Konsep Pendidikan Islam Bagi Remaja Menurut Zakiah Daradjat Zulkifli Agus}

goncang dapat merusak dan mengancam pertumbuhan jiwa anak, apabila dihadapi oleh orang tua yang tidak bijaksana, maka di sini peranan ibu sangat menentukan dalam membimbingnya ke arah kehidupan yang sehat dan diridhoi oleh Allah SWT.(Zakiah Daradjat,1990:12-13).

Peranan orang tua atau ayah dan ibu dalam memberikan pendidikan kepada remaja sangat utama, keluarga bukan hanya unit terkecil dalam masyarakat, melainkan lebih dari itu, yakni sebagai lembaga kehidupan manusia yang memberi peluang untuk memilih hidup celaka atau bahagia di dunia dan di akhirat. Dan setiap remaja sedikit atau banyak kepribadiannya adalah cerminan dari orang tuanya, atau bentuk penentangan kepada orang tuanya yang tidak memahami remaja.

b) Guru

Guru adalah pendidik profesional, karenanya secara implisit ia telah merelakan dirinya menerima dan memikul sebagian tanggung jawab pendidikan yang terpikul di pundak para orang tua.

Orang tua tatkala menyerahkan anaknya ke sekolah, sekaligus berarti pelimpahan sebagian tanggung jawab pendidikan anaknya kepada guru. Hal itu pun menunjukkan pula bahwa orang tua tidak mungkin menyerahkan anaknya kepada sembarang guru/sekolah karena tidak sembarang orang dapat menjadi guru.(Zakiah Daradjat,2014: 39).

Lebih lanjut, guru harus sanggup menilai diri sendiri tanpa berlebih-lebihan, sanggup berkomunikasi dan bekerja bersama dengan orang lain. Selain itu perlu diperhatikan pula dalam hal mana ia memiliki kemampuan dan kelamahan.(Zakiah daradjat,2008: 266). Guru yang melaksanakan tugas pengajaran merupakan orangorang yang telah dibekali dengan pengetahuan tentang anak didik dan memiliki kemampuan untuk melaksanakan kependidikan. Atas dasar itulah Zakiah Daradjat menyebut guru sebagai pendidik profesional.

Berangkat dari analisa di atas, dapat dikatakan guru menempati tempat istimewa di dalam kehidupan sebagian besar remaja. Guru adalah orang dewasa yang berhubungan erat dengan remaja. Dalam pandangan remaja, guru merupakan cerminan dari alam luar. Remaja percaya bahwa guru sebagai contoh dari masyarakat secara keseluruhan. Dan remaja menyangka bahwa semua orang tua, kecuali orang tua mereka, berpikir seperti berpikirnya guru-guru mereka.(Zakiah Daradjat,1995: 25)

Namun di pihak lain, didapati bahwa remaja mungkin memandang gurunya sebagai ganti dari orang tuanya. Apabila remaja memandang guru seperti memandang orang tuanya, maka mereka condong untuk mempunyai perasaan terhadap guru seperti perasaannya terhadap orang tuanya, akan tetapi mereka mungkin merasa lebih bebas mengungkapkan perasaannya. Zakiah Daradjat mengungkapkan, “Remaja dapat mengkritik guru secara terbuka. Kadang-kadang 
Volume 4 Nomor 1 Edisi Juni 2019

P-ISSN : 2541-3686

mereka merasa lebih mudah untuk mengungkapkan rasa kagum kepada guru, akan tetapi mereka ragu untuk mengungkapkannya kepada orang tuanya."

Faktor terpenting bagi seorang guru adalah kepribadiannya. Kepribadian itulah yang akan menentukan apakah ia menjadi pendidik atau pembina yang baik bagi anak-didiknya, ataukah akan menjadi perusak atau penghancur bagi hari depan anak-didik, terutama bagi anak-didik yang masih kecil (tingkat sekolah dasar) dan mereka yang sedang mengalami kegoncangan jiwa (tingkat menengah).(Zakiah Daradjat,2005:25). Karena remaja tidak memerlukan pemimpin yang suka memerintah, tapi mereka memerlukan pembimbing yang mengerti, mau dan dapat memahami gejolak jiwa dan goncangan emosi yang sedang melandanya. Hanya guru yang bijaksana mengerti yang mereka perlukan.(Zakiadh Daradjat,2005:58). Dan guru yang ideal dalam pandangan remaja adalah guru yang mampu menjangkau perasaan remaja dan menghargai serta mendorong mereka untuk aktif dalam kegiatan sekolah serta suka memberikan penilaian yang obyektif. Guru yang terbuka hatinya untuk mendengarkan keluhan murid-muridnya, bagi remaja dipandang sebagai konselor di sekolah itu.

Maka tidak diragukan lagi, bahwa rasa empati dari guru dan pemahamannya yang mendalam terhadap masalah dan konflik yang dihadapi remaja, serta perlakuan yang didasarkan atas penghargaan terhadap diri dan kepribadian remaja, akan mendapat kepercayaan remaja dan mereka mau mengungkapkan persoalan dan perasaannya.(Zakiah Darajat,1995: 27).

Dengan ringkas dapat dikatakan bahwa fungsi utama seorang guru adalah mengetahui tuntutan perkembangan remaja, dan mengetahui kemampuan dan bakat. Guru juga harus memberikan petunjuk dan bimbingan yang diperlukan untuk menciptakan kepribadian bagi remaja dengan syarat guru hendaknya bertakwa kepada Allah, berilmu, sehat jasmaninya, baik akhlaknya, bertanggung jawab dan berjiwa nasional.

c) Masyarakat

Masyarakat turut serta memikul tanggung jawab pendidikan. Secara sederhana masyarakat dapat diartikan sebagai kumpulan individu dan kelompok yang diikat oleh kesatuan negara, kebudayaan dan agama. Oleh karena itu Zakiah Daradjat menjelaskan bahwa masyarakat besar pengaruhnya dalam memberi arah terhadap pendidikan anak, terutama para pemimpin masyarakat atau penguasa yang ada di dalamnya. Pemimpin masyarakat muslim tentu saja menghendaki agar setiap anak dididik menjadi anggota yang taat dan patuh menjalankan agamanya, baik dalam lingkungan keluarganya, anggota sepermainannya, kelompok kelasnya dan sekolahnya. Bila anak telah besar diharapkan menjadi anggota yang baik pula sebagai warga desa, warga kota dan warga negara.(Zakiah Daradjat,2015: 44-45).

Akan tetapi ada hal yang menggelisahkan remaja, adalah tampaknya perbedaan antara nilai-nilai akhlak yang diajarkan oleh agama dengan kelakuan 


\section{Konsep Pendidikan Islam Bagi Remaja Menurut Zakiah Daradjat Zulkifli Agus}

orang dalam masyarakat. Terutama yang sangat menggelisahkan remaja, apabila pertentangan itu terlihat pada orang tua, guru-gurunya di sekolah, pemimpinpemimpin dan tokoh-tokoh agama. Semakin besar perbedaan antara nilai-nilai agama dan kelakuan orang-orang yang dihargai dan dihormatinya, akan semakin goncang jiwa remaja, sasaran utama dari kekecewaannya akan ditujukan kepada tokoh-tokoh agama, karena mereka mengharapkan tokoh agama yang harus menjaga dan memperbaiki akhlak masyarakat. (Zakiah Daradjat,2015: 137).

Dengan demikian, di pundak masyarakat terpikul keikutsertaan membimbing pertumbuhan dan perkembangan remaja yang berarti bahwa pemimpin dan penguasa dari masyarakat ikut bertanggung jawab terhadap penyelenggaraan pendidikan. Sebab tanggung jawab pendidikan pada hakikatnya merupakan tanggung jawab moral dari setiap orang dewasa baik sebagai perseorangan maupun sebagai kelompok sosial. Tanggung jawab ini ditinjau dari segi ajaran Islam, secara implisit mengandung pula tanggung jawab pendidikan.(Zakiah Daradjat,2015:45). Dari analisa di atas dapat diuraikan bahwa masyarakat harus memberikan teladan antara keselarasan nilai-nilai akhlak bersama dengan kenyataan kelakuan orang-orang dalam masyarakat. Jika hal itu tidak diperoleh remaja, maka remaja akan kecewa. Dan akan lebih baik untuk remaja apabila pendidikan agama memberikan jalan dan kesempatan kepada remaja untuk melaksanakan ajaran agama itu dalam kehidupan yang luas dan mereka menemukan contoh-contoh yang perlu mereka teladani dalam hidup, serta mendapat bimbingan praktis.

Selanjutnya, Heri Jauhari Muchtar menuliskan dalam "Fikih Pendidikan", tentunya melalui pendidikan Islam, ada beberapa saran atau nasihat yang dikemukakan oleh Zakiah Daradjat sehubungan dengan pembinaan dan pendidikan terhadap remaja, yaitu:

1) Tunjukkan pengertian dan perhatian terhadap mereka.

2) Bantulah remaja untuk mendapatkan rasa aman.

3) Timbulkan pada remaja bahwa dia sayang.

4) Hargai dan hormati mereka.

5) Berilah remaja kebebasan dalam batas-batas tertentu (kebebasan yang tidak melanggar norma-norma agama).

6) Timbulkan pada remaja rasa butuh agama.

7) Sediakan waktu dan sarana untuk berkonsultasi dengan mereka.

8) Usahakan agar mereka merasa berhasil.(Heri Jauhari Muchtar,2005: 71).

Diharapkan dengan kedelapan saran tersebut dapat membantu orang tua ataupun guru dalam mendidik dan membimbing remaja sehingga menjadi generasi yang cerdas dan shalih serta kreatif. 
Volume 4 Nomor 1 Edisi Juni 2019

P-ISSN : 2541-3686

\section{Fungsi Pendidikan Islam bagi Remaja}

Islam adalah adalah suatu agama yang berisi ajaran tentang tata hidup yang diturunkan Allah kepada umat manusia melalui para rasul-Nya, sejak dari Nabi Adam sampai kepada Nabi Muhammad SAW. Ajaran ini diturunkan Allah untuk kesejahteraan hidup manusia di dunia ini dan di akhirat nanti.

Ajaran yang dibawa oleh Nabi Muhammad ini, lebih lengkap dan lebih sempuran dari ajaran yang dibawa oleh nabi-nabi sebelumnya dan nama "Islam" diresmikan pemakaiannya pada masa Nabi Muhammad ini.(Zakiah Daradjat,2014: 59-60). Karena ajaran Islam ini memuat ajaran tentang tata hidup yang meliputi seluruh aspek kehidupan manusia, maka jelaslah agama Islam memiliki fungsi bagi kehidupan manusia, terkhusus remaja.

a) Memberikan Bimbingan dalam Hidup

Pengendali kehidupan manusia adalah kepribadiannya yang mencakup segala unsur-unsur pengalaman, pendidikan dan keyakinan yang didapatnya sejak kecil.

Agama yang ditanamkan sejak kecil kepada anak-anak sehingga merupakan bagian dari unsur-unsur kepribadiannya, akan cepat bertindak menjadi pengendali dalam menghadapi segala keinginan-keinginan dan dorongan-dorongan yang timbul. Karena keyakinan terhadap agama yang menjadi bagian dari kepribadian itu, akan mengatur sikap dan tingkah laku seseorang secara otomatis dari dalam.(Zakiah Daradjat,1985:57).

Sebagai contoh Zakiah Daradjat memberikan gambaran dalam menghadapi dorongan-dorongan biologis, yang mulai timbul setelah pertumbuhan jasmani atau setelah masa puber, bagi orang yang tidak beragama, pengendali satu-satunya adalah masyarakat. Jika masyarakat di mana ia hidup membenarkan dipenuhinya kebutuhan-kebutuhan biologis itu di luar perkawinan, maka akan mudahlah orang melakukan permainan itu tanpa merasa bersalah, seperti terjadi di beberapa negara modern, di mana sudah sangat sukar untuk mencari gadis yang masih perawan. Di samping itu akan didapati pula gadis-gadis yang sudah mempunyai anak. Hubungan seksual yang dilakukan di luar perkawinan itu, akan membuka pintu bagi terjadinya penyakit-penyakit kelamin dan yang akan menderita lebih banyak adalah anak-anak yang lahir, yang tidak jelas siapa ayahnya.

Bagi orang yang beragama, kendatipun ia hidup dalam masyarakat yang serba modern itu, ia tetap akan berusaha mengendalikan dirinya ketika terasa dorongan-dorongan seksual itu.(Zakiah Daradjat,1985:57-58). Penolong dalam Kesukaran

Bagi orang yang beragama, kesukaran atau bahaya sebesar apapun yang harus dihadapinnya, namun ia akan waras dan sabar, karena dia merasa bahwa kesukaran dalam hidup itu merupakan bagian dari percobaan Allah kepada hambaNya yang beriman. Ia tidak memandang setiap kesukaran atau ancaman terhadap 


\section{Konsep Pendidikan Islam Bagi Remaja Menurut Zakiah Daradjat Zulkifli Agus}

dirinya dengan cara negatif, akan tetapi sebaliknya melihat bahwa di celah-celah kesukaran tersebut terdapat harapan-harapan. Dia tidak akan menyalahkan orang lain atau mencari sebab-sebab negatif pada orang lain.(Zakiah Daradjat,1988: 60).

b) Menentramkan Batin

Betapa gelisahnya anak-anak muda yang tidak pernah menerima didikan agama. Karena usia muda itu adalah usia di mana jiwa sedang bergejolak, penuh dengan kegelisahan dan pertentangan batin dan banyak dorongan yang menyebabkan lebih gelisah lagi. Maka agama bagi anak muda mempunyai fungsi penentram batin dan penenang jiwa, di samping itu menjadi pengendali moral.(Zakiah Daradjat,1988: 62).

Jadi jelas dapat dirasakan bahwa pendidikan Islam dalam hal keimanan/agama memberikan bimbingan dalam hidup, penolong dalam kesukaran dan menentramkan batin agar terhindar dari hal yang tidak bermanfaat bahkan hal yang bisa menghancurkan diri remaja. Bagi remaja agama merupakan bibit terbaik yang diperlukan dalam pembinaan kepribadiannya. Remaja yang tidak pernah mendapat didikan agama di waktu kecilnya, tidak akan merasakan kebutuhan terhadap agama di kala dewasa nanti.

\section{Simpulan}

Berdasarkan analisis penelitian, maka dapat diambil simpulan: Pendidikan dalam Islam begitu penting sehingga merupakan suatu kewajiban, karena pendidikan dapat mengubah manusia dari tidak tahu menjadi tahu. Terkhusus pendidikan pada remaja adalah hal yang diharapkan akan memberikan bimbingan untuk mendorong remaja menjadi generasi yang beragama dan jiwanya sehat.

Kebutuhan kejiwaan remaja banyak dipengaruhi oleh lingkungan dan kebudayaan masyarakat di mana ia tinggal. Remaja memerlukan kebutuhankebutuhan tertentu yang sesuai dengan perkembangan emosinya. Kebutuhan tersebut jika tidak dapat terpenuhi akan menyebabkan kemerosotan akhlak pada remaja, karena remaja sudah dapat menilai secara logis dan memerlukan penjelasan yang logis juga terhadap suatu yang ingin diketahuinya.

Pendidikan pada remaja adalah pendidikan yang Islami, dalam arti Islami mengadung makna bahwa setiap jenis pendidikan yang diberikan pada remaja harus dengan nilai agama (Islam), karena nilai agama merupakan ajaran yang absolut, berlaku sepanjang zaman sehingga nilai-nilai yang lainnya mengikuti nilainilai Islam.

Tanggung jawab pendidikan pada remaja terletak dan dipengaruhi oleh orang tua, guru, dan masyarakat. Dengan demikian bahwa tanggung jawab pendidikan dalam Islam bersifat perseorangan dan sosial sekaligus.

Peranan agama sebagai fungsi pendidikan Islam bagi remaja sangat penting. Karena remaja yang memiliki dasar-dasar agama akan lebih mudah dikembalikan 
RAUDHAH Proud To Be Professionals Jurnal Tarbiyah)damiyah

Volume 4 Nomor 1 Edisi Juni 2019

P-ISSN : 2541-3686

pada jiwanya yang beragama apabila ia melenceng perbuatannya, jika dibandingkan dengan remaja yang tidak dibekali pendidikan agama akan goncang sampai ia dewasa.

\section{Saran-Saran}

Dari simpulan di atas diharapkan akan memberikan sumbangsih untuk pendidikan remaja di sekitar lingkungan hidup. Untuk orang tua, guru dan setiap individu dewasa yang dekat dengan remaja hendaknya memahami kebutuhan, perkembangan dan karakteristik remaja. Dengan begitu bisa lebih mudah memberi pengertian, bimbingan serta nilai-nilai yang sesuai dengan kenyataan yang dilihat oleh remaja. Karena remaja bukanlah manusia yang bermaksud menyeleweng, atau membangkang namun ia ingin dimengerti sebagai makhluk sosial yang membutuhkan pengajaran, terkhusus pendidikan Islam yang lebih bisa menenangkan jiwa remaja, apabila mereka dihadapkan dengan masalah. 
Konsep Pendidikan Islam Bagi Remaja Menurut Zakiah Daradjat

Zulkifli Agus

\section{DAFTAR PUSTAKA}

\section{Al-Quranul Karim}

Daradjat, Zakiah. 1982. Perawatan Jiwa untuk Anak-anak. Jakarta: Bulan Bintang. 1985. Pembinaan Jiwa/Mental. Jakarta: Bulan Bintang. 1985. Perkawinan Yang Bertanggung Jawab. Jakarta: Bulan Bintang.

Masagung. 1988. Peranan Agama dalam Kesehatan Mental. Jakarta: Haji . 1990. Islam dan Peranan Wanita. Jakarta: Bulan Bintang. . 1993. Ketenangan dan Kebahagiaan dalam Keluarga. Jakarta: Bulan Bintang. 1993. Dasar-dasar Agama Islam. Jakarta: Bulan Bintang. 1993. Pendidikan Islam dalam Keluarga dan Sekolah. Jakarta: Ruhama. 1995. Remaja Harapan dan Tantangan. Jakarta: Ruhama. 2002. Psikoterapi Islami. Jakarta: Bulan Bintang. 2005. Kepribadian Guru. Jakarta: Bulan Bintang. 2015. Ilmu Jiwa Agama. Jakarta: Bulan Bintang.

Daradjat, Zakiah, dkk. 2008. Metodologi Pengajaran Agama Islam. Jakarta: Bumi Aksara. . 2014. Ilmu Pendidikan Islam. Jakarta: Bumi Akasara. 2014. Metodik Khusus Pengajaran PAI. Jakarta: Bumi Akasara.

Departemen Agama RI. 2009. Al-Qur'an dan Terjemahnya. Bandung: PT Sygma Examedia Arkanleema.

Jauhari Muchtar, Heri. 2005. Fikih Pendidikan. Bandung: Remaja Rosda Karya. 